\title{
Visions of a truly nourishing dinner
}

Book review by Matt Hess *

World Hunger Relief, Inc.

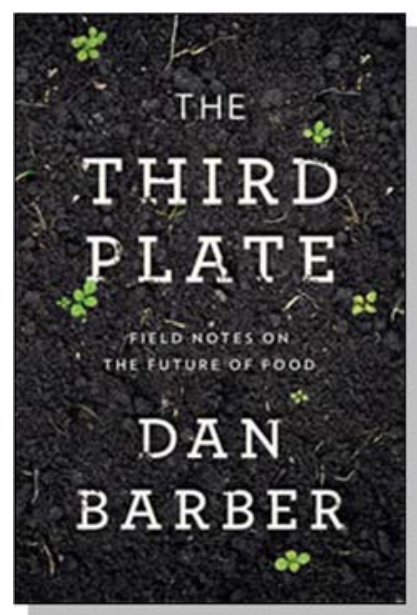

\author{
Review of The Third Plate: Field Notes on The Future of Food, \\ by Dan Barber. (2014). New York: Penguin Press. Available in \\ hardcover, paperback, ebook, and audiobook (for download or as \\ CDs); 496 pages. Publisher's website: http://www.penguin.com/ \\ book/the-third-plate-by-dan-barber/9780698163751
}

Published online May 19, 2015

Citation: Hess, M. (2015). Visions of a truly nourishing dinner [Book review]. Journal of Agriculture, Food Systems, and Community Development, 5(3), 153-155. http://dx.doi.org/10.5304/jafscd.2015.053.003

Copyright (C) 2015 by New Leaf Associates, Inc.

$\mathrm{I}_{\mathrm{t}}^{\mathrm{t}}$ first encountered Dan Barber's The Third Plate: Field Notes on The Future of Food while doing research for a session I was asked to lead for the Texas Chefs Association annual convention. In a quick Google search looking for inspiration I found Barber's book. In this work the author provides a handy tool to describe the evolution of food over the last 20 years and the hope of a meal

* Matt Hess, Executive Director, World Hunger Relief, Inc.; 356 Spring Lake Road; Waco, Texas 76705 USA; +1-254-7995611; matt@worldhungerrelief.org

Matt Hess grew up in Boulder, Colorado, and then moved to Waco, Texas, to attend Baylor University, where he received a bachelor of science in education in history. Afterward he stayed in Waco and taught at a school for troubled youth. As a teacher, he saw the difference that working with animals and gardens made on his students, and he began volunteering at WHRI partially with the intention of developing more skills in agriculture and community development. Matt joined World Hunger Relief, Inc., as the education director in 2006 years and six years later transitioned to his current role as executive director. that could nourish and sustain a better world. I feel it is worthwhile to let Barber describe the three meals that reflect this evolution:

The first plate was a seven-ounce corn-fed steak with a small side of vegetables (I chose steamed baby carrots) - in other words, the American expectation of dinner for much of the past half-century. It was never an enlightened or particularly appetizing construction, and at this point it's thankfully passé.

The second plate represented where we are now, infused with all the ideals of the farm-to-table movement. The steak was grass-fed, the carrots were now a local heirloom variety grown in organic soil. Inasmuch as it reflected all of the progress American food has experienced in the past decade, the striking thing about the second plate was that it looked nearly identical to the first. 
Finally, the third plate kept with the steak-dinner analogy —only this time, the proportions were reversed. In place of a hulking piece of protein, I imagined a carrot steak dominating the plate, with a sauce of braised second cuts of beef.

The point wasn't to suggest that we'll be reduced to eating meat only in sauces, or that vegetable steaks are the future of food. It was to predict that the future of cuisine will represent a paradigm shift, a new way of thinking about cooking and eating that defies Americans' ingrained expectations. I was looking toward a new cuisine, one that goes beyond raising awareness about the provenance of ingredients and-like all great cuisines-begins to reflect what the landscape can provide. (p. 17)

I include this longer quotation to allow Barber to share his thesis and also to allow his expressive, natural writing style to come through. The reader is entertained through storytelling that is in turn autobiographical, biographical, and historical, but not in a rigid pattern. Barber shares the agricultural principals related to soil fertility, weed management, and botany necessary for the consumer to be a true participant in the farm-to-table dialog. He also draws the reader into the lives and passions of some of the most interesting characters in that movement.

The chefs at the conference, especially those with East Cost ties, were more aware of Barber and his impact on eating than I, so this framework of three plates gave me a handy point of access to a notoriously exclusionary community. The first plate still dominates in Texas; in fact, a 7 oz. $(198 \mathrm{~g})$ steak is normally listed on the menu with a feminine reference of some kind. Especially in larger cities, however, restaurants and eaters are moving toward the second plate in the analogy. Many Southern chefs may skip over the second plate to the third in their attempts to be avantgarde, environmentally responsible, or nostalgic, as we have the advantage down in the South to have a culinary heritage that looks similar to the third plate.

Collard greens, black-eyed peas garnished with bacon, and corn bread, when grown and served with heart and skill, are an embodiment of the values Barber and his band of farmers, writers, and cooks share in this work. It would be easy to look back on this meal with nostalgia, ignoring the oppression of land and people that led to this diet. Thankfully, Barber recognizes this temptation and early in the work reminds us that our nation's agricultural heritage is one of exploitation, made easy by the land's fertility and bounty and a replaceable labor force. So instead of looking backward we are encouraged to look to those farmers and activists who nourish their soil so that it can nourish its people while redeeming the best parts of our culinary history.

This was my call to the chefs, and I believe it is Barber's call to us: that we should love food more, and place more value upon it. Barber calls us to resist the pull to either produce food as inexpensively as possible or limit what we consume as a means of rationing the limited supply of resources this planet has to offer. We have the chance for a cuisine that provides health and healing for people, place, and planet when we value it more.

This book is also a handy primer on the names and texts of the movement away from extractive agriculture and toward an agriculture that brings health in all its meanings. Barber makes quick summaries of the contributions of the usual suspects of authors, giving a handy guide to the sources one needs to know about in order to participate in the dialogue. (A fairly exhaustive list of books including some lesser known and more specialized texts is included in the back.)

Barber refers to the technological and cultural changes brought on by wars and conflict, especially World War II, which marks a significant change in the trajectory of any line graph representing the way food is grown and eaten, especially in North America. He also directly addresses the fact that the same nations that waged these wars also create policy and behave in ways that radically influence the way food is produced, delivered, and consumed. What Barber fails to bring up is the critical point that agriculture has always had two motivations: the first motivation is the feeding of people, while the second — which has dictated the way a majority of our calories are harvested - is the 
advancement of empires.

The cuisines of cultures are heavily influenced by the political will of governments. The Green Revolution may have been started with the intention of improving the lives of millions, but it quickly became apparent to both the first world (capitalist countries led by the U.S.) and the second world (communist countries led by the Soviet Union) that these technologies could be used to put food on the plates of the third world and keep them from shifting to the other side. The protection and expansion of empire has influenced agriculture from its beginnings and will play an important role in shaping the diets of tomorrow.

The chef certainly holds a position of power from which he or she can influence the trends of food consumption. There is precedence to show that trends that start at the priciest eateries trickle down to the rest of us eaters, but if we ignore the way public policy has shaped the history of agriculture then we risk ignoring the ways in which these same forces are shaping what we will be eating 30 years from now. Despite the omission of political forces that have shaped our diet, many who have read all of Michael Pollan's and Wendell Berry's work will be grateful for a source of new knowledge and inspiration. The volume is not brief, at nearly 450 pages, and gets into more detail than someone who is casually interested may be willing to dig through, but The Third Plate is accessible enough that someone who is new to the movement should be able to digest it. 